\title{
Light absorption enhancement of black carbon in urban Beijing in summer
}

\section{Xie, Conghui}

2019-09-15

Xie, C, Xu , W, Wan , J, Liu, D, Ge , X, Zhang, Q, Wang, Q, Du , W, Zhao, J, Zhou , W , Li , J , Fu , P , Wang , Z , Worsnop , D \& Sun , Y 2019 , ' Light absorption enhancement of black carbon in urban Beijing in summer ' , Atmospheric Environment, vol. 213 , pp. 499-504 . https://doi.org/10.1016/j.atmosenv.2019.06.041

http://hdl.handle.net/10138/331698

https://doi.org/10.1016/j.atmosenv.2019.06.041

cc_by_nc_nd

acceptedVersion

Downloaded from Helda, University of Helsinki institutional repository.

This is an electronic reprint of the original article.

This reprint may differ from the original in pagination and typographic detail.

Please cite the original version. 


\section{Light Absorption Enhancement of Black Carbon in Urban Beijing in}

\section{Summer}

4 Conghui Xie ${ }^{1,2}$, Weiqi Xu ${ }^{1,2}$, Junfeng Wang, ${ }^{3, a}$, Dantong Liu ${ }^{4}$, Xinlei Ge ${ }^{3}$, Qi Zhang ${ }^{5}$, Qingqing

$5 \quad$ Wang $^{1}$,Wei Du ${ }^{1,2, b}$, Jian Zhao ${ }^{1,2}$, Wei Zhou ${ }^{1,2}, \mathrm{Jie} \mathrm{Li}^{1}$, Pingqing $\mathrm{Fu}^{6,2}$, Zifa Wang ${ }^{1,2,8}$, Douglas

6 Worsnop $^{7}$, Yele Sun ${ }^{1,2,8^{*}}$

$8{ }^{1}$ State Key Laboratory of Atmospheric Boundary Layer Physics and Atmospheric Chemistry,

9 Institute of Atmospheric Physics, Chinese Academy of Sciences, Beijing 100029, China

$10 \quad{ }^{2}$ College of Earth and Planetary Sciences, University of Chinese Academy of Sciences, Beijing 11 100049, China

$12{ }^{3}$ School of Environmental Science and Engineering, Nanjing University of Information Science \&

13 Technology, Nanjing 210044, China

$14{ }^{4}$ Department of Atmospheric Sciences, School of Earth Sciences, Zhejiang University, Hangzhou, 15 Zhejiang, China

$16{ }^{5}$ Department of Environmental Toxicology, University of California, 1 Shields Ave., Davis, CA

17 95616, USA

$18{ }^{6}$ Institute of Surface-Earth System Science, Tianjin University, Tianjin 300072, China

$19{ }^{7}$ Aerodyne Research, Inc., Billerica, MA 01821, USA

$20{ }^{8}$ Center for Excellence in Regional Atmospheric Environment, Institute of Urban Environment,

21 Chinese Academy of Sciences, Xiamen 361021, China

22 anow at: School of Engineering and Applied Sciences, Harvard University, Cambridge 02138, USA

23 bnow at: Institute for Atmospheric and Earth System Research / Physics, Faculty of Science,

24 University of Helsinki, Helsinki, Finland

26 Correspondence: Yele Sun (sunyele@mail.iap.ac.cn) 


\section{ABSTRACT}

28 The light absorption enhancement $\left(E_{\mathrm{abs}}\right)$ of black carbon (BC) caused by non-BC materials is an

29 important source of uncertainty in radiative forcing estimate, yet remains poorly understood in

30 relatively polluted environment such as the megacity Beijing. Here BC absorption enhancement at

$31630 \mathrm{~nm}$ was in-situ measured using a thermodenuder coupled with a soot particle aerosol mass

32 spectrometer and a single scattering albedo monitor in Beijing in summer. The project average $( \pm 1 \sigma)$

$33 E_{\text {abs }}$ was 1.59 ( \pm 0.26), suggesting a significant amplification of $\mathrm{BC}$ absorption due to coating

34 materials. $E_{\text {abs }}$ presented a clear daytime increase due to enhanced photochemical processing, and a

35 strong dependence on the mass ratios of non-BC coatings to $B C\left(R_{B C}\right)$. Our results showed that the

36 increase in $E_{\mathrm{abs}}$ as a function of $\mathrm{R}_{\mathrm{BC}}$ was mainly caused by the increased contributions of secondary

37 aerosol. Further analysis showed that the BC absorption enhancement in summer in Beijing was

38 mainly associated with secondary formation of nitrate, sulfate and highly oxidized secondary organic

39 aerosol (SOA), while the formation of freshly and less oxidized SOA appeared not to play an

40 important role.

\section{Key Words:}

43 Black carbon; Absorption enhancement; Secondary aerosol; Beijing 


\section{Introduction}

Black carbon aerosol (BC), a by-product of incomplete combustion carbonaceous matter (e.g.

biomass and fossil fuel) is recognized as the third most important global warming agent after $\mathrm{CO}_{2}$ and $\mathrm{CH}_{4}$ (Stocker et al., 2013). BC exerts a great impact on climate change by absorbing direct solar radiation, reducing cloud albedo, and accelerating the melt of snow (Bond et al., 2013). Accurate estimate of light absorption of BC is thus important to improve our understanding on the impacts of these processes on climate radiative forcing.

The BC absorption is enhanced by its coating materials (Lack and Cappa, 2010), and the

52 enhancement can be significant by a factor of 2 when $\mathrm{BC}$ is internally mixed with other

53 components (Bond and Bergstrom, 2006; Chandra, 2004; Shiraiwa et al., 2010). In contrast, the

54 freshly emitted BC tend to be fractal-like and externally mixed with other components (Peng et al., 55 2016), and has no absorption enhancement (Liu et al., 2017). The freshly emitted BC can be aged 56 rapidly in the atmosphere (Glen, 2010; Moteki et al., 2007), which changes the mixing state, 57 morphology, coating thickness of BC and thereby its absorbing properties. Current climate models 58 usually use a constant enhancement factor ( 1.5) to estimate the radiative forcing of BC (Chung and 59 Seinfeld, 2008; Wang et al., 2014b). However, a recent study showed that the BC absorption 60 enhancements ( $\left.E_{\mathrm{abs}}\right)$ should be treated as a function of particle mixing state (Liu et al., 2017).

61 Previous studies also showed significant differences in BC absorption enhancement in different

62 regions. For example, the field measurements during CALNex and CARES in California showed

63 small BC enhancements ( 6\%) and the enhancements were weakly dependent on photochemical 64 aging (Cappa et al., 2012). Small absorption enhancement were also observed at Nagoya (Japan) 
65 (Nakayama et al., 2015) and Shenzhen in China(Lan et al., 2013), due to the fact that a large fraction

66 of aerosol species was externally mixed with BC. Liu et al (2015) found that the magnitude of BC

67 absorption enhancement depends strongly on coating amount, which varies largely for different

68 sources and regions. In fact, light absorption enhancement of $\sim 1.8-2.2$ were observed in heavily

69 polluted areas such as Indo-Gangetic Plain (Thamban et al., 2017), Xi’an (Wang et al., 2014a), and

70 Yucheng(Cui et al., 2016). Peng et al. (2016) found that BC in polluted urban environment (Beijing,

71 China) aged much faster than that in a relatively clean area (Houston, USA), and the absorption

72 enhancement can be up to a factor of 2.4 in a few hours' ageing. Despite previous efforts in

73 characterization of BC absorption enhancements in different regions, in situ measurements of $E_{\text {abs }}$ is

74 still limited, particularly in relatively polluted region in China.

75 In this work, the $E_{\mathrm{abs}}$ of $\mathrm{BC}$ was measured in urban Beijing in summer using a thermodenuder

76 coupled with a soot particle aerosol mass spectrometer (SP-AMS) and a cavity attenuated phase shift

77 single scattering albedo monitor (CAPS PM $\mathrm{ssa}_{\mathrm{sa}}$ ). The variation of $E_{\mathrm{abs}}$ in Beijing in summer and its

78 relationship with $\mathrm{BC}$ coating materials are elucidated, and the major factors affecting $E_{\mathrm{abs}}$ are

79 investigated.

\section{$80 \quad 2$ Experimental methods}

81 All measurements were conducted from 4 June to 13 June, 2017 at the Institute of Atmospheric

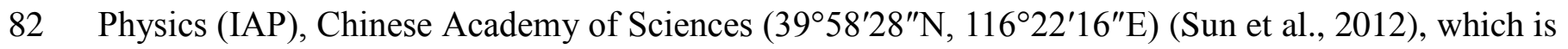

83 located between north $3^{\text {rd }}$ and $4^{\text {th }}$ ring roads in Beijing. The instruments were deployed on the roof of

84 a two-story building ( $\sim \mathrm{m})$. Ambient air was first drawn into the sampling room through a 1/2 inch 
85 stainless steel tubing with a flow rate of $3 \mathrm{~L} \mathrm{~min}^{-1}$. After passing through a diffusion silica-gel dryer,

86 aerosol particles $\left(\sim 1.5 \mathrm{~L} \mathrm{~min}^{-1}\right)$ were sub-sampled into a thermodenuder (TD), and then measured by

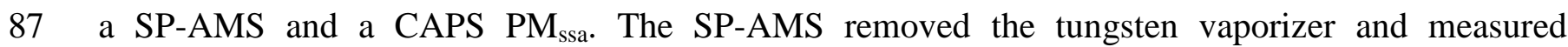

88 refractory $\mathrm{BC}(\mathrm{rBC})$ and $\mathrm{rBC}$-containing species only. The CAPS $\mathrm{PM}_{\mathrm{ssa}}$ measured particle extinction

$89\left(b_{\text {ext }}\right)$ and scattering coefficients $\left(b_{\text {sca }}\right)$ at $630 \mathrm{~nm}$, and the difference between $b_{\text {ext }}$ and $b_{\text {sca }}$ was

90 absorption coefficient $\left(b_{\mathrm{abs}}\right)$. Although the $b_{\text {sca }}$ measurements had uncertainties due to truncation

91 effects, our previous studies showed that such an effect was small, and $b_{\text {abs }}$ derived from the CAPS

$92 \quad \mathrm{PM}_{\text {ssa }}$ was highly correlated with that measured by photoacoustic extinctiometer and aethalometer

93 (Han et al., 2015; Xie et al., 2019). In this study, the measurements were alternated between TD and

94 bypass line every 10 min (Fig. S1), and the TD cycled through four temperature gradients (50, 100,

95 150, and $260{ }^{\circ} \mathrm{C}$ ). The TD loss was corrected with rBC measured by the SP-AMS considering that

$96 \mathrm{rBC}$ does not evaporate at $260{ }^{\circ} \mathrm{C}$. The meteorological data including temperature, relative humidity,

97 wind speed and wind direction (Fig. S2) were obtained from the measurements on the Beijing $325 \mathrm{~m}$

98 meteorological tower.

99 In addition, a single-particle soot photometer (SP2, Droplet Measurement Technologies) was

100 used to measure the spherical equivalent core diameter $\left(D_{c}\right)$ and the particle diameter $\left(D_{\mathrm{p}}\right)$ at the

101 same site (Liu et al., 2018). The $D_{\mathrm{p}} / D_{\mathrm{c}}$ in this study is calculated as the bulk relative coating

102 thickness which reflects the integrated coated BC volume and uncoated BC core volume for a given

103 time window. The bulk $D_{\mathrm{p}} / D_{\mathrm{c}}$ is largely independent of the uncertainties arising from smaller

104 particles because of their less important contribution to the integrated volume, therefore, the retrieval

105 rate of successful coating thickness decreases at smaller and larger $D_{c}$, because of the reduced 
106 signal-to-noise level for the scattering signal of smaller particle and the detector saturation for larger

107 particle. The uncertainty associated with the missing single particle coating information is examined

108 at each $D_{c}$ range by extrapolating the coating thickness at the most populated BC in mass with

109 coating retrieval rate $>80 \%$. The resulting uncertainties are by $7-11 \%$ for the BC with bulk $D_{p} / D_{c}>2$,

$110 \quad 3-8 \%$ at $D_{p} / D_{c} 1.5-2$ and $0.5-3 \%$ with $D_{p} / D_{c} 1-1.5$. Recent study indicates this bulk $\mathrm{D}_{\mathrm{p}} / \mathrm{D}_{\mathrm{c}}$ metric is

111 able to produce the total coating mass associated with BC particles within 25\% (Ting et al., 2018).

112 The $E_{\text {abs }}$ was calculated as the ratio of ambient particle absorption $\left(b_{\mathrm{abs} \text {, ambient }}\right)$ to that passing

113 through the TD at $260{ }^{\circ} \mathrm{C}\left(b_{\mathrm{abs}}, \mathrm{TD}\right)$. As shown in Fig. S3, 76\% of non-BC aerosol species evaporated

114 at $260{ }^{\circ} \mathrm{C}$, and the remaining fraction was dominated by rBC and hydrocarbon-like OA(HOA)-rich

115 primary aerosol and more oxidized oxygenated OA (MO-OOA) that were resolved from positive

116 matrix factorization of high-resolution mass spectra of OA of the SP-AMS (Wang et al., 2019b).

117 Therefore, $E_{\text {abs }}$ might have a slight underestimation due to the lensing effect of residual materials on

118 BC. $E_{\text {abs, MAC }}$ can also be estimated as the ratio of measured mass absorption coefficient $\left(\mathrm{MAC}_{\mathrm{obs}}=\right.$

$\left.119 b_{\text {abs, ambient }} / \mathrm{rBC}\right)$ to the reference MAC $\left(\mathrm{MAC}_{\mathrm{ref}}=6.55 \mathrm{~m}^{2} \mathrm{~g}^{-1}\right)$ for uncoated $\mathrm{BC}$ at $630 \mathrm{~nm}$. The

120 MAC $_{\text {ref }}$ was derived from the power law dependence of absorption on wavelength with a MAC of

$1217.5 \mathrm{~m}^{2} \mathrm{~g}^{-1}$ at $550 \mathrm{~nm}$ (Bond and Bergstrom, 2006). $E_{\text {abs }}$ was well correlated with $E_{\text {abs, MAC }}\left(\mathrm{r}^{2}=0.66\right)$,

122 and the average values were also close (1.59 \pm 0.26 and $1.63 \pm 0.41$, respectively), suggesting that

123 these two methods were overall consistent. Therefore, $E_{\text {abs }}$ discussed below referred to the TD-CAPS

124 method unless otherwise stated. 
The average $( \pm 1 \sigma) E_{\text {abs }}$ was $1.59( \pm 0.26)$ for the entire study suggesting approximately $60 \%$

127 light absorption enhancement by BC coatings. Such an enhancement was overall consistent with

$128 \sim 1.5$ that is often used in current climate models (Flanner et al., 2007), and agreed with the recent

129 observations at the SIRTA facility (Zhang et al., 2018a) and UK winter (Liu et al., 2015). However, it

130 was much higher than that previously reported in California regions with limited BC absorption

131 enhancement due to coatings (Cappa et al., 2019).

$132 E_{\mathrm{abs}}$ depends strongly on the mass ratios of coating materials on $\mathrm{BC}$ to $\mathrm{rBC}\left(\mathrm{R}_{\mathrm{BC}}\right)$ that were from 133 the SP-AMS_measurements in Beijing in summer. As shown in Fig. 1a, $E_{\text {abs }}$ increased substantially as 134 a function of $\mathrm{R}_{\mathrm{BC}}$. As $\mathrm{R}_{\mathrm{BC}}$ increased from 2 to $6, E_{\mathrm{abs}}$ increased by $45 \%$ from 1.34 to 1.94 . Such an $135 \mathrm{R}_{\mathrm{BC}}$ dependence of $E_{\mathrm{abs}}$ was remarkably similar to that observed in UK winter although aerosol 136 composition was substantially different (Liu et al., 2015). However, we did not observe further 137 increases in $E_{\mathrm{abs}}$ as $\mathrm{R}_{\mathrm{BC}}$ was larger than 6. One explanation was the few data points increasing the 138 uncertainties for $E_{\text {abs }}$ estimates. Another possibility is that $E_{\text {abs }}$ was stabilized as BC was fully aged 139 with a high $\mathrm{R}_{\mathrm{BC}}$ (Wu et al., 2018). Fig. 1b shows that the aerosol composition of rBC coatings varied 140 significantly as a function of $\mathrm{R}_{\mathrm{BC}}$. As $\mathrm{R}_{\mathrm{BC}}$ increased from 2 to 6 , the mass fraction of non-BC POA 141 (rBC-rich+HOA-rich) decreased from 54\% to 14\%, while the contributions of secondary aerosol 142 species (= SOA+SIA) increased from $45 \%$ to $85 \%$. These results indicate that the increases in $E_{\text {abs }}$ of 143 BC were mainly caused by the enhanced contributions from secondary formation in Beijing in 144 summer. Comparatively, the fractions of primary and secondary aerosol species were relatively stable 145 during periods with $\mathrm{R}_{\mathrm{BC}}>6$, which might also explain the negligible increases of $E_{\mathrm{abs}}$. Compared 
146 with summer, our previous winter studies in 2016 showed that non-BC aerosol composition was

147 dominated by POA ( $>\sim 60 \%$ ) at $\mathrm{R}_{\mathrm{BC}}<4.5$, and the contribution of secondary aerosol species

148 increased rapidly to $\sim 80 \%$ as $\mathrm{R}_{\mathrm{BC}}$ increased up to 7 . As a result, the MAC of $\mathrm{BC}$ at $630 \mathrm{~nm}$ in winter

149 was relatively stable below $\mathrm{R}_{\mathrm{BC}}<4.5$, and then increased by approximately $40 \%$ during periods with

150 high $\mathrm{R}_{\mathrm{BC}}$ (Xie et al., 2019). This is consistent with the conclusion in summer that BC absorption

151 enhancement was mainly associated with secondary coatings, while the influences of non-BC POA

152 on $E_{a b s}$ were generally small.

153 We also compared the measured $E_{\mathrm{abs}}$ with that derived from the Mie core-shell model by

154 assuming refractive index of $\mathrm{rBC}$ core and coatings at $550 \mathrm{~nm}$ as $1.95+0.79 \mathrm{i}$ and $1.50+0 \mathrm{i}$,

155 respectively (Liu et al., 2018). The $\mathrm{R}_{\mathrm{BC}}$ from SP2 measurements was calculated using Eq. 1. The

156 density of $\mathrm{rBC}$ is $1.8 \mathrm{~g} \mathrm{~cm}^{-3}$ and that $\left(1.3 \pm 0.05 \mathrm{~g} \mathrm{~cm}^{-3}\right)$ of coatings was estimated based on the

157 chemical composition of BC-containing aerosol particles (Zhao et al., 2017).

$$
R_{B C}=\left(\left(\frac{D_{p}}{D_{\mathrm{r}}}\right)^{a}-1\right) \times \frac{\rho_{\text {conting }}}{\rho_{\text {rac }}}
$$

159 As shown in Fig. 1a, the $\mathrm{R}_{\mathrm{BC}}$ dependence of simulated $E_{\mathrm{abs}}$ was similar, while the simulated $E_{\mathrm{abs}}$ were 160 slightly lower than those from the ambient TD measurements (Fig. 1a).

Fig. 2a shows that $E_{\text {abs }}$ increased as a function of particulate matter (PM) loadings suggesting

162 stronger significant BC absorption enhancements during periods with higher pollution levels. For 163 instance, $E_{\text {abs }}$ increased from $\sim 1.4$ to 1.8 as $\mathrm{PM}_{1}$ mass loading increased from $\sim 10$ to $50 \mu \mathrm{g} \mathrm{m}{ }^{-3}$. We 164 found that such enhancements were mainly associated with the increases in $\mathrm{rBC}$ coatings $\left(\mathrm{R}_{\mathrm{BC}}\right)$, 165 which is consistent with previously simulations (Zhang et al., 2018b) and chamber experiments in 166 Beijing (Peng et al., 2016). However, we did not observe a clear rBC dependence of $E_{\text {abs }}$ in summer, 
167 consistent with the small variations in $\mathrm{R}_{\mathrm{BC}}$, and even slight decreases at high $\mathrm{rBC}$ loadings $(>2 \mu \mathrm{g}$

$168 \mathrm{~m}^{-3}$ ). This is different from winter when $\mathrm{R}_{\mathrm{BC}}$ showed a considerable increase as a function of $\mathrm{rBC}$

169 (Liu et al., 2018). Such differences can be explained by the differences in rBC sources and coating

170 materials between summer and winter. In winter, high rBC concentration was associated with high

171 POA from coal combustion and biomass burning emissions (Wang et al., 2019a), while in summer it

172 was dominantly from traffic emissions ( $\mathrm{Hu}$ et al., 2016). The coating materials were also

173 substantially different between summer and winter. For example, SIA and SOA on average

174 accounted for $21 \%$ and $34 \%$ of the total BC-containing particle mass in summer (Xu et al., 2019),

175 while they were 20.1\% and 20.8\%, respectively in winter (Wang et al., 2019a). Previous studies

176 showed that $\mathrm{rBC}$ from traffic emissions has smaller $\mathrm{R}_{\mathrm{BC}}$ compared with those from other combustion

177 sources, such as biomass burning and coal combustion (Liu et al., 2018). In fact, $\mathrm{R}_{\mathrm{BC}}$ was

178 anticorreleated with rBC mass loading near vehicular emissions (Lee et al., 2017) while it was

179 positively correlated with rBC under high pollution with multiple sources of rBC (Lee et al., 2017;

180 Zhang et al., 2018b).

181 We further evaluated the influence of chemical composition of rBC coatings on $E_{\text {abs. }}$ As shown

182 in Fig. 3, the changes in $E_{\mathrm{abs}}$ as a function of $\mathrm{R}_{\mathrm{BC}}$ depended strongly on non-BC composition. The

183 periods with higher contributions of nitrate and sulfate showed correspondingly higher $E_{\text {abs }}$

184 throughout different $\mathrm{R}_{\mathrm{BC}}$. For example, $E_{\mathrm{abs}}$ was increased by $7-21 \%$ during periods with higher

185 nitrate contributions (> 10\%), while $6-17 \%$ for periods with higher sulfate contributions (> 10\%).

186 These results suggest that secondary nitrate and sulfate coated on BC have the most impacts on

187 absorption enhancement. One explanation is that the increased nitrate and sulfate changed the BC 
mixing state to the core-shell structure and thus increased the absorption enhancement (He et al.,

189 2015). For example, recent studies showed that the increases in ammonium nitrate and sulfate can

190 reduce the deliquescence RH substantially and cause phase transitions of aerosol particles (Sun et al.,

191 2018). During periods with high contents of nitrate and sulfate, the BC-containing particles would be

192 more like in concentric core-shell structure due to the changes of particle phase states from solid to

193 aqueous phase, and hence lead to significant light absorption enhancement. Fig. 3 also shows very

194 different impacts of OA factors on BC absorption enhancement. The increased contribution of

195 MO-OOA presented a positive effect on absorption enhancement by approximately $6-7 \%$. However,

196 LO-OOA and HOA decreased $E_{\text {abs }}$ by 7 - 11\% during periods with high contributions (10\% and $15 \%$,

197 respectively). Such results indicate that formation of freshly oxidized SOA in summer appears not an

198 important factor driving the increase of $\mathrm{BC}$ absorption enhancement. The decrease of $E_{\mathrm{abs}}$ as the

199 increase of HOA contribution was due to 1) vehicle emission with low $\mathrm{R}_{\mathrm{BC}}$ has a very limited

200 influence on light absorption enhancement, and 2) the increase of HOA was associated with the

201 corresponding decreases in rBC coatings of sulfate, nitrate, and MO-OOA (Fig. 3). Considering that

$202 E_{\text {abs }}$ calculated from the TD method could be affected by the residual mass at $260{ }^{\circ} \mathrm{C}$, we further

203 checked the composition dependent relationship between $E_{\mathrm{abs}, \mathrm{MAC}}$ and $\mathrm{R}_{\mathrm{BC}}$ (Fig. S4). As shown in

204 Fig. S4, similar conclusions were obtained that formation of secondary inorganic aerosol can impact

205 BC absorption enhancement significantly while that of SOA has limited influences and even

206 decreases $E_{\text {abs }}$. Our results were different from a recent study in the megacity of Paris, France

207 showing a major contributor of SOA to BC absorption enhancement in summer (Zhang et al., 2018a).

208 One reason was due to the very different aerosol composition between Beijing and Paris. While SOA 
209 contributed more than half (52\%) of submicron aerosol in Paris in summer, it was much lower (27\%)

210 in Beijing.

211 The light absorption enhancement of BC presents a strong diurnal variation in Beijing in summer.

$212 E_{\text {abs }}$ gradually increased from $\sim 1.5$ in the morning to $\sim 1.8$ at 12:00 - 13:00, and then decreased

213 slowly to 1.4 at midnight. Such a diurnal trend was overall similar to that of $\mathrm{R}_{\mathrm{BC}}$, photochemical age

214 indicated by $-\log \left(\mathrm{NO}_{\mathrm{x}} / \mathrm{NO}_{\mathrm{y}}\right)$, and ratios of secondary nitrate and sulfate to $\mathrm{rBC}\left(\mathrm{NO}_{3} / \mathrm{rBC}\right.$ and

$215 \mathrm{SO}_{4} / \mathrm{rBC}$, respectively). These results indicate that photochemical processing played a dominant role

216 in changing rBC coatings and absorption enhancement in summer (Fig. 1c), which is different from

217 the observations in California (Cappa et al., 2012) showing limited dependence of $E_{\mathrm{abs}}$ on

218 photochemical aging. However, we also noticed the differences in aerosol composition and BC

219 mixing states before and after noontime. As shown in Fig. 4, $\mathrm{NO}_{3} / \mathrm{rBC}$ showed the largest increase

220 from 8:00 to 12:00, while the variations in $\mathrm{SO}_{4} / \mathrm{rBC}$ were relatively small, suggesting that the first

221 increase in $E_{a b s}$ in daytime was mainly driven by nitrate formation. Although $\mathrm{SO}_{4} / \mathrm{rBC}$,

$222 \mathrm{MO}-\mathrm{OOA} / \mathrm{rBC}$, and $-\log \left(\mathrm{NO}_{\mathrm{x}} / \mathrm{NO}_{\mathrm{y}}\right)$ continued to increase after noontime between 12:00 and 16:00,

$223 E_{a b s}$ decreased slowly instead. We found that $\mathrm{R}_{\mathrm{BC}}$ and $\mathrm{D}_{\mathrm{p}} / \mathrm{D}_{\mathrm{c}}$ remained relatively unchanged during

224 this period, while $\mathrm{NO}_{3} / \mathrm{rBC}$ showed a clear decrease due to the evaporative loss of nitrate associated

225 with high temperature. Such results are consistent with the conclusion above that $E_{\text {abs }}$ is sensitive to

226 the coating fractions of nitrate.

\section{Conclusion}

228 The absorption of BC remains a large uncertainty for estimating global warming due to the 
229 controversial lensing effect of absorption enhancement. Here we provide direct evidence for BC

230 absorption enhancement in Beijing in summer using the in situ measurements by a thermodenuder

231 coupled with SP-AMS and single scattering albedo monitor. Our results showed that the average $E_{\text {abs }}$

232 at $630 \mathrm{~nm}$ was $1.59( \pm 0.26)$ indicating a substantial absorption enhancement due to rBC coatings.

$233 E_{\mathrm{abs}}$ showed a strong dependence on $\mathrm{rBC}$ coatings $\left(\mathrm{R}_{\mathrm{BC}}\right)$, and the increases in $E_{\mathrm{abs}}$ were mainly

234 caused by the production of secondary aerosol species. Further support was from the significant

235 daytime increase in $E_{\mathrm{abs}}$ that was associated with enhanced photochemical processing and the

236 formation of secondary organic and inorganic species. By characterizing the composition dependent

$237 E_{\mathrm{abs}}$, we found that the increases in $E_{\mathrm{abs}}$ showed different sensitivities to different aerosol species.

238 Formation of secondary nitrate and sulfate in summer has the most impacts on BC absorption

239 enhancements, while freshly oxidized SOA appears not important. Our results highlight an urgent

240 need to characterize the changes of BC mixing states due to the formation of secondary organic and

241 inorganic aerosol species, and the changes of particle phase states.

243 Acknowledgements.

244 This work was supported by the National Natural Science Foundation of China (91744207, 245 41575120, 41571130034) and the National Key R\&D Program of China (2017YFC0212704, 246 2017YFC0209601).

247 Notes

248 The authors declare no competing financial interest. 


\section{References}

251 Bond, T.C., Bergstrom, R.W., 2006. Light Absorption by Carbonaceous Particles: An Investigative Review. Aerosol Science and Technology 40, 27-67.

Bond, T.C., Doherty, S.J., Fahey, D.W., Forster, P.M., Berntsen, T., DeAngelo, B.J., Flanner, M.G., Ghan, S., Kärcher, B., Koch, D., Kinne, S., Kondo, Y., Quinn, P.K., Sarofim, M.C., Schultz, Hopke, P.K., Jacobson, M.Z., Kaiser, J.W., Klimont, Z., Lohmann, U., Schwarz, J.P., Shindell, D., Storelvmo, T., Warren, S.G., Zender, C.S., 2013. Bounding the role of black carbon in the climate system: A scientific assessment. J. Geophys. Res. 118, 5380-5552.

Cappa, C.D., Onasch, T.B., Massoli, P., Worsnop, D.R., Bates, T.S., Cross, E.S., Davidovits, P., Hakala, J., Hayden, K.L., Jobson, B.T., Kolesar, K.R., Lack, D.A., Lerner, B.M., Li, S.-M., Mellon, D., Nuaaman, I., Olfert, J.S., Petäjä, T., Quinn, P.K., Song, C., Subramanian, R., Williams, E.J., Zaveri, R.A., 2012. Radiative Absorption Enhancements Due to the Mixing State of Atmospheric Black Carbon. Science 337, 1078-1081.

Cappa, C.D., Zhang, X., Russell, L.M., Collier, S., Lee, A.K.Y., Chen, C.-L., Betha, R., Chen, S., Liu, J., Price, D.J., Sanchez, K.J., McMeeking, G.R., Williams, L.R., Onasch, T.B., Worsnop, D.R., Abbatt, J., Zhang, Q., 2019. Light absorption by ambient black and brown carbon and its dependence on black carbon coating state for two California, USA cities in winter and summer. Journal of Geophysical Research: Atmospheres.

Chandra, S., 2004. Can the state of mixing of black carbon aerosols explain the mystery of 'excess' atmospheric absorption? Geophysical Research Letters 31.

Chung, S.H., Seinfeld, J.H., 2008. Climate response of direct radiative forcing of anthropogenic black carbon. Journal of Geophysical Research Atmospheres 110, -.

Cui, X., Wang, X., Yang, L., Chen, B., Chen, J., Andersson, A., Gustafsson, O., 2016. Radiative absorption enhancement from coatings on black carbon aerosols. Sci Total Environ 551-552, 51-56.

Flanner, M.G., Zender, C.S., Randerson, J.T., Rasch, P.J., 2007. Present-day climate forcing and response from black carbon in snow. Journal of Geophysical Research 112. 
Glen, C.C., 2010. Observations of secondary organic aerosol production and soot aging under atmospheric conditions using a novel environmental aerosol chamber. Dissertations \& Theses Gradworks.

Han, T., Xu, W., Chen, C., Liu, X., Wang, Q., Li, J., Zhao, X., Du, W., Wang, Z., Sun, Y., 2015. Chemical apportionment of aerosol optical properties during the Asia-Pacific Economic Cooperation summit in Beijing, China. J. Geophys. Res. 120, 12,281-212,295.

He, C., Liou, K.N., Takano, Y., Zhang, R., Levy Zamora, M., Yang, P., Li, Q., Leung, L.R., 2015. Variation of the radiative properties during black carbon aging: theoretical and experimental intercomparison. Atmospheric Chemistry and Physics 15, 11967-11980.

Hu, W., Hu, M., Hu, W., Jimenez, J.L., Yuan, B., Chen, W., Wang, M., Wu, Y., Chen, C., Wang, Z., Peng, J., Zeng, L., Shao, M., 2016. Chemical composition, sources, and aging process of submicron aerosols in Beijing: Contrast between summer and winter. Journal of Geophysical Research: Atmospheres 121, 1955-1977.

Lack, D.A., Cappa, C.D., 2010. Impact of brown and clear carbon on light absorption enhancement, single scatter albedo and absorption wavelength dependence of black carbon. Atmospheric Chemistry and Physics 10, 4207-4220.

Lan, Z.-J., Huang, X.-F., Yu, K.-Y., Sun, T.-L., Zeng, L.-W., Hu, M., 2013. Light absorption of black carbon aerosol and its enhancement by mixing state in an urban atmosphere in South China. Atmospheric Environment 69, 118-123.

Lee, A.K.Y., Chen, C.-L., Liu, J., Price, D.J., Betha, R., Russell, L.M., Zhang, X., Cappa, C.D., 2017. Formation of secondary organic aerosol coating on black carbon particles near vehicular emissions. Atmospheric Chemistry and Physics 17, 15055-15067.

Liu, D., Joshi, R., Wang, J., Yu, C., Allan, J.D., Coe, H., Flynn, M.J., Xie, C., Lee, J., Squires, F., Kotthaus, S., Grimmond, S., Ge, X., Sun, Y., Fu, P., 2018. Contrasting physical properties of black carbon in urban Beijing between winter and summer. Atmos. Chem. Phys. Discuss. 2018, $1-30$.

Liu, D., Whitehead, J., Alfarra, M.R., Reyes-Villegas, E., Spracklen, Dominick V., Reddington, Carly L., Kong, S., Williams, Paul I., Ting, Y.-C., Haslett, S., Taylor, Jonathan W., Flynn, 
Michael J., Morgan, William T., McFiggans, G., Coe, H., Allan, James D., 2017. Black-carbon absorption enhancement in the atmosphere determined by particle mixing state. Nat. Geosci. 10, 184-188.

Liu, S., Aiken, A.C., Gorkowski, K., Dubey, M.K., Cappa, C.D., Williams, L.R., Herndon, S.C., Massoli, P., Fortner, E.C., Chhabra, P.S., Brooks, W.A., Onasch, T.B., Jayne, J.T., Worsnop, D.R., China, S., Sharma, N., Mazzoleni, C., Xu, L., Ng, N.L., Liu, D., Allan, J.D., Lee, J.D., Fleming, Z.L., Mohr, C., Zotter, P., Szidat, S., Prevot, A.S., 2015. Enhanced light absorption by mixed source black and brown carbon particles in UK winter. Nat. Commun. 6, 8435.

Moteki, N., Kondo, Y., Miyazaki, Y., Takegawa, N., Komazaki, Y., Kurata, G., Shirai, T., Blake, D.R., Miyakawa, T., Koike, M., 2007. Evolution of mixing state of black carbon particles: Aircraft measurements over the western Pacific in March 2004. Geophysical Research Letters 34.

Nakayama, T., Ikeda, Y., Sawada, Y., Setoguchi, Y., Ogawa, S., Kawana, K., Mochida, M., Ikemori, F., Matsumoto, K., Matsumi, Y., 2015. Properties of light - absorbing aerosols in the Nagoya urban area, Japan, in August 2011 and January 2012: Contributions of brown carbon and lensing effect. Journal of Geophysical Research Atmospheres 119, 12,721-712,739.

Peng, J., Hu, M., Guo, S., Du, Z., Zheng, J., Shang, D., Levy, Z.M., Zeng, L., Shao, M., Wu, Y.S., 2016. Markedly enhanced absorption and direct radiative forcing of black carbon under polluted urban environments. Proc. Natl. Acad. Sci. U.S.A.

Shiraiwa, M., Kondo, Y., Iwamoto, T., Kita, K., 2010. Amplification of Light Absorption of Black Carbon by Organic Coating. Aerosol Science and Technology 44, 46-54.

Stocker, T.F., Qin, D., Plattner, G.K., Tignor, M., Allen, S.K., Boschung, J., Nauels, A., Xia, Y., Bex, V., Midgley, P.M., 2013. Climate Change 2013: The Physical Science Basis. Intergovernmental Panel on Climate Change, Working Group I Contribution to the IPCC Fifth Assessment Report (AR5). Cambridge University Press: New York.

Sun, J., Liu, L., Xu, L., Wang, Y., Wu, Z., Hu, M., Shi, Z., Li, Y., Zhang, X., Chen, J., Li, W., 2018. Key Role of Nitrate in Phase Transitions of Urban Particles: Implications of Important Reactive Surfaces for Secondary Aerosol Formation. Journal of Geophysical Research: Atmospheres 123, 1234-1243. 
Sun, Y., Wang, Z., Dong, H., Yang, T., Li, J., Pan, X., Chen, P., Jayne, J.T., 2012. Characterization of summer organic and inorganic aerosols in Beijing, China with an Aerosol Chemical Speciation Monitor. Atmospheric Environment 51, 250-259.

Thamban, N.M., Tripathi, S.N., Moosakutty, S.P., Kuntamukkala, P., Kanawade, V.P., 2017. Internally mixed black carbon in the Indo-Gangetic Plain and its effect on absorption enhancement. Atmospheric Research 197, 211-223.

Ting, Y., Mitchell, E., Allan, J., Liu, D., Spracklen, D., Williams, A., Jones, J.M., Lea-Langton, A.R., McFiggans, G., Coe, H., 2018. The Mixing State of Carbonaceous Aerosols of Primary Emissions from 'Improved' African Cookstoves. Environ. Sci. Technol.

Wang, J., Liu, D., Ge, X., Wu, Y., Shen, F., Chen, M., Zhao, J., Xie, C., Wang, Q., Xu, W., Zhang, J., Hu, J., Allan, J., Joshi, R., Fu, P., Coe, H., Sun, Y., 2019a. Characterization of black carbon-containing fine particles in Beijing during wintertime. Atmospheric Chemistry and Physics 19, 447-458.

Wang, J., X., G., Wu, Y., Shen, F., Chen, M., Zhao, J., Xie, C., Wang, Q., Xu, W., Sun, Y., $2019 b$. Characterization of black carbon-containing fine particles in Beijing during summertime: Contrast between SP-AMS and HR-AMS, in preparation.

Wang, Q., Huang, R.J., Cao, J., Han, Y., Wang, G., Li, G., Wang, Y., Dai, W., Zhang, R., Zhou, Y., 2014a. Mixing State of Black Carbon Aerosol in a Heavily Polluted Urban Area of China: Implications for Light Absorption Enhancement. Aerosol Science and Technology 48, 689-697. Wang, Q., Jacob, D.J., Spackman, J.R., Perring, A.E., Schwarz, J.P., Moteki, N., Marais, E.A., Ge, C., Wang, J., Barrett, S.R.H., 2014b. Global budget and radiative forcing of black carbon aerosol: Constraints from pole to pole (HIPPO) observations across the Pacific. Journal of Geophysical Research Atmospheres 119, 195-206.

Wu, Y., Cheng, T., Liu, d., Allan, J., Zheng, L., Chen, H., 2018. Light absorption enhancement of black carbon aerosol constrained by particle morphology. Environmental Science \& Technology.

Xie, C., Xu, W., Wang, J., Wang, Q., Liu, D., Tang, G., Chen, P., Du, W., Zhao, J., Zhang, Y., Zhou, W., Han, T., Bian, Q., Li, J., Fu, P., Wang, Z., Ge, X., Allan, J., Coe, H., Sun, Y., 2019. Vertical 
characterization of aerosol optical properties and brown carbon in winter in urban Beijing, China. Atmospheric Chemistry and Physics 19, 165-179.

364 Xu, W., Xie, C., Karnezi, E., Zhang, Q., Wang, J., Pandis, S.N., Ge, X., Wang, Q., Zhao, J., Du, W., 365 Qiu, Y., Zhou, W., He, Y., Zhang, J., An, J., Li, Y., Li, J., Fu, P., Wang, Z., Worsnop, D.R., Sun, 366 Y., 2019. Summertime aerosol volatility measurements in Beijing, China. Atmospheric 367 Chemistry and Physics Discussions, 1-19.

368 Zhang, Y., Favez, O., Canonaco, F., Liu, D., Močnik, G., Amodeo, T., Sciare, J., Prévôt, A.S.H., Gros, 369 V., Albinet, A., 2018a. Evidence of major secondary organic aerosol contribution to lensing 370 effect black carbon absorption enhancement. npj Climate and Atmospheric Science 1.

371 Zhang, Y., Zhang, Q., Cheng, Y., Su, H., Li, H., Li, M., Zhang, X., Ding, A., He, K., $2018 b$.

372 Amplification of light absorption of black carbon associated with air pollution. Atmospheric 373 Chemistry and Physics 18, 9879-9896.

374 Zhao, J., Du, W., Zhang, Y., Wang, Q., Chen, C., Xu, W., Han, T., Wang, Y., Fu, P., Wang, Z., Li, Z., 375 Sun, Y., 2017. Insights into aerosol chemistry during the 2015 China Victory Day parade: results 376 from simultaneous measurements at ground level and $260 \mathrm{~m}$ in Beijing. Atmos. Chem. Phys. 17, 377 3215-3232. 

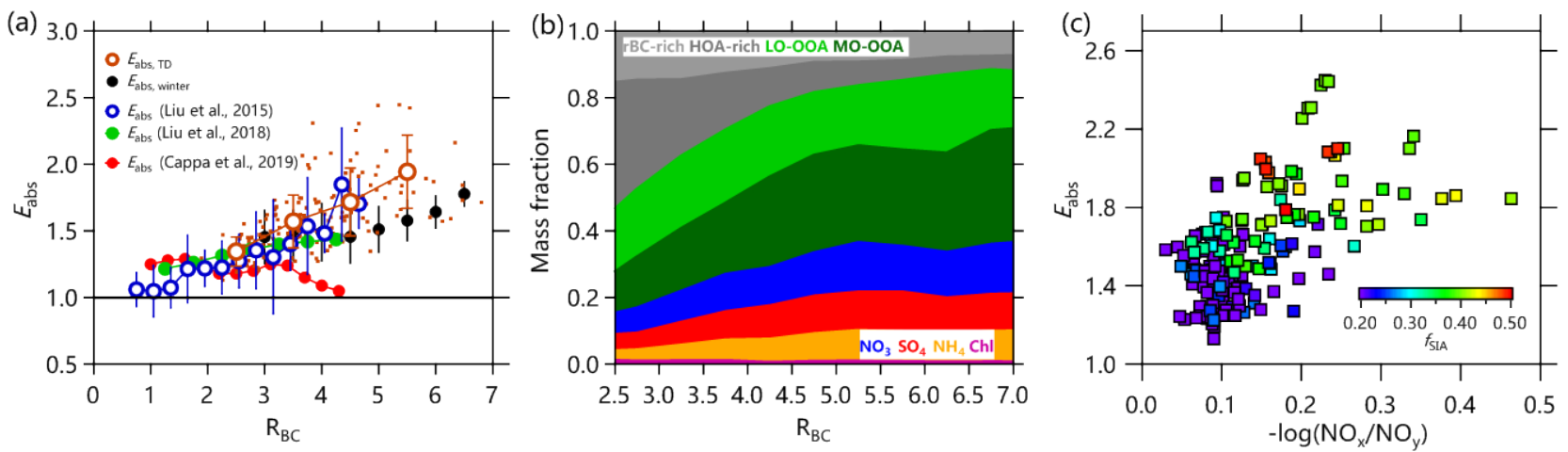

380 Fig. 1. (a) $\mathrm{BC}$ absorption enhancement as a function of $\mathrm{R}_{\mathrm{BC}}$. Also shown are the $E_{\mathrm{abs}}$ measurements at $532 \mathrm{~nm}$ in UK winter (Liu et al., 2015) and Fresno, California (Cappa et al., 2019). The $E_{\text {abs }}$ in winter in Beijing was calculated as the MAC divided by $7.4 \mathrm{~m}^{2} \mathrm{~g}^{-1}$ (Xie et al., 2019). In addition, $E_{\text {abs }}$ in Beijing summer was also modeled with the SP2 measurements (Liu et al., 2018). The error bars in 384 the figure are one standard deviations. (b) Chemical composition of rBC coatings as a function of $385 \mathrm{R}_{\mathrm{BC}}$, and (c) scatter plot of $E_{\mathrm{abs}}$ versus $-\log \left(\mathrm{NO}_{\mathrm{x}} / \mathrm{NO}_{\mathrm{y}}\right)$ color coded by the fraction of secondary 386 inorganic aerosol $\left(f_{\text {SIA }}\right)$.
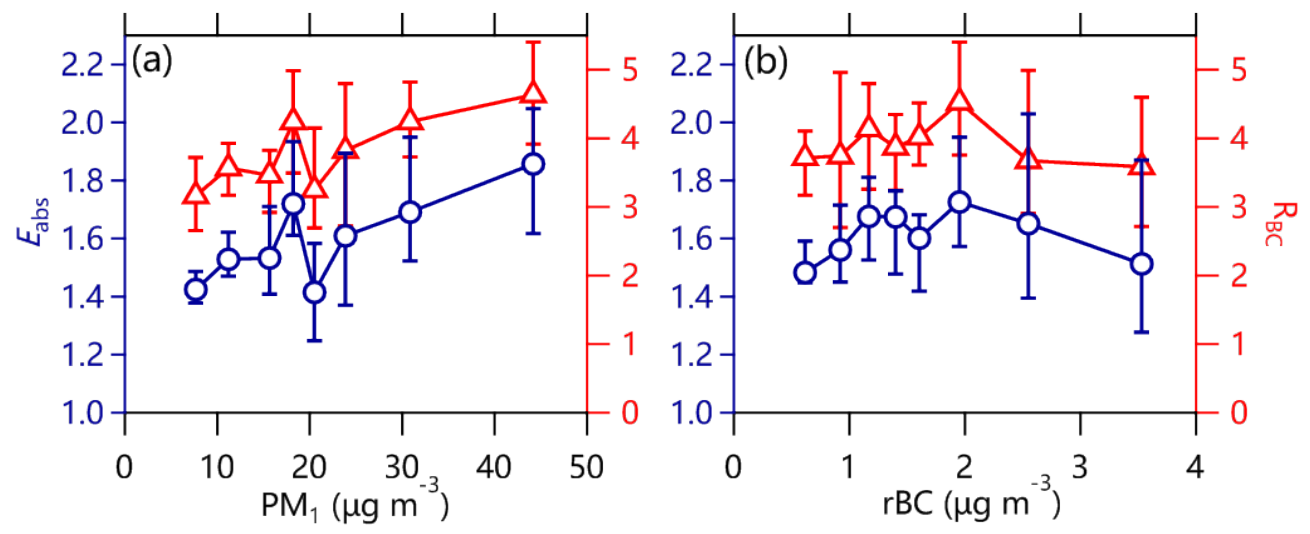

389

Fig. 2. Variations of $E_{\mathrm{abs}}$ and $\mathrm{R}_{\mathrm{BC}}$ as a function of (a) $\mathrm{PM}_{1}$ mass loadings and (b) $\mathrm{rBC}$ concentrations.

The bottom and top error bars represent $25^{\text {th }}$ and $75^{\text {th }}$ percentiles. 

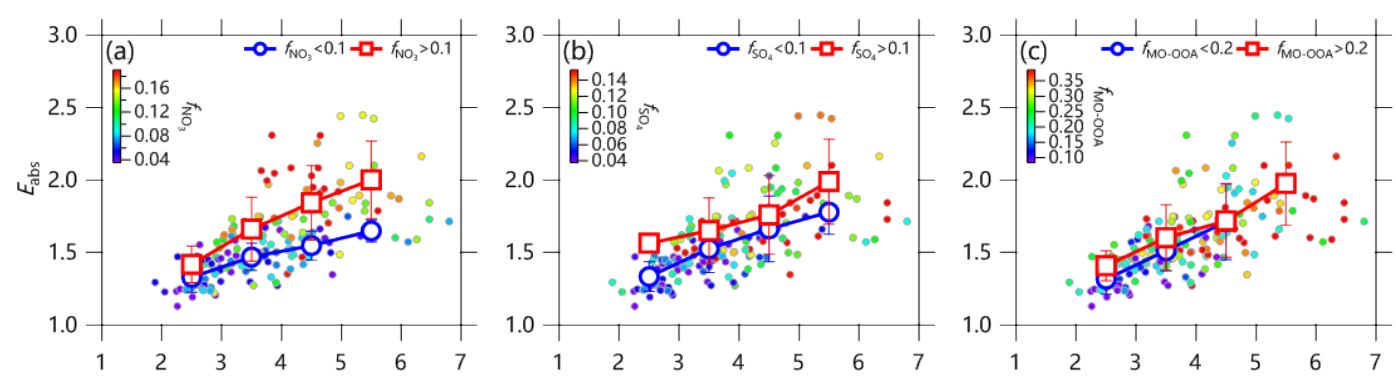

394 Fig. 3. Variations of $\mathrm{BC}$ absorption enhancement as a function of $\mathrm{R}_{\mathrm{BC}}$, color coded by mass fractions
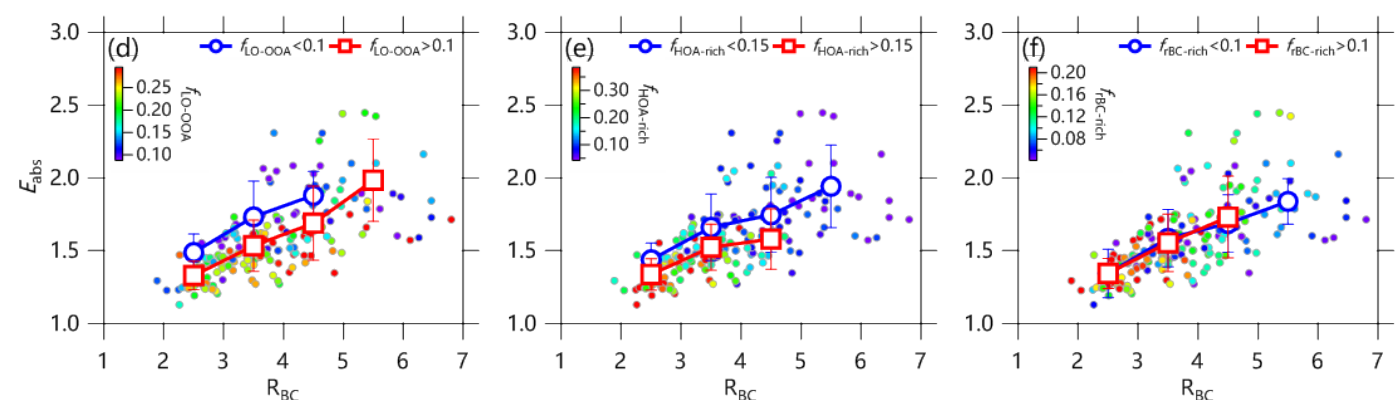
and the error bars are one standard deviations.
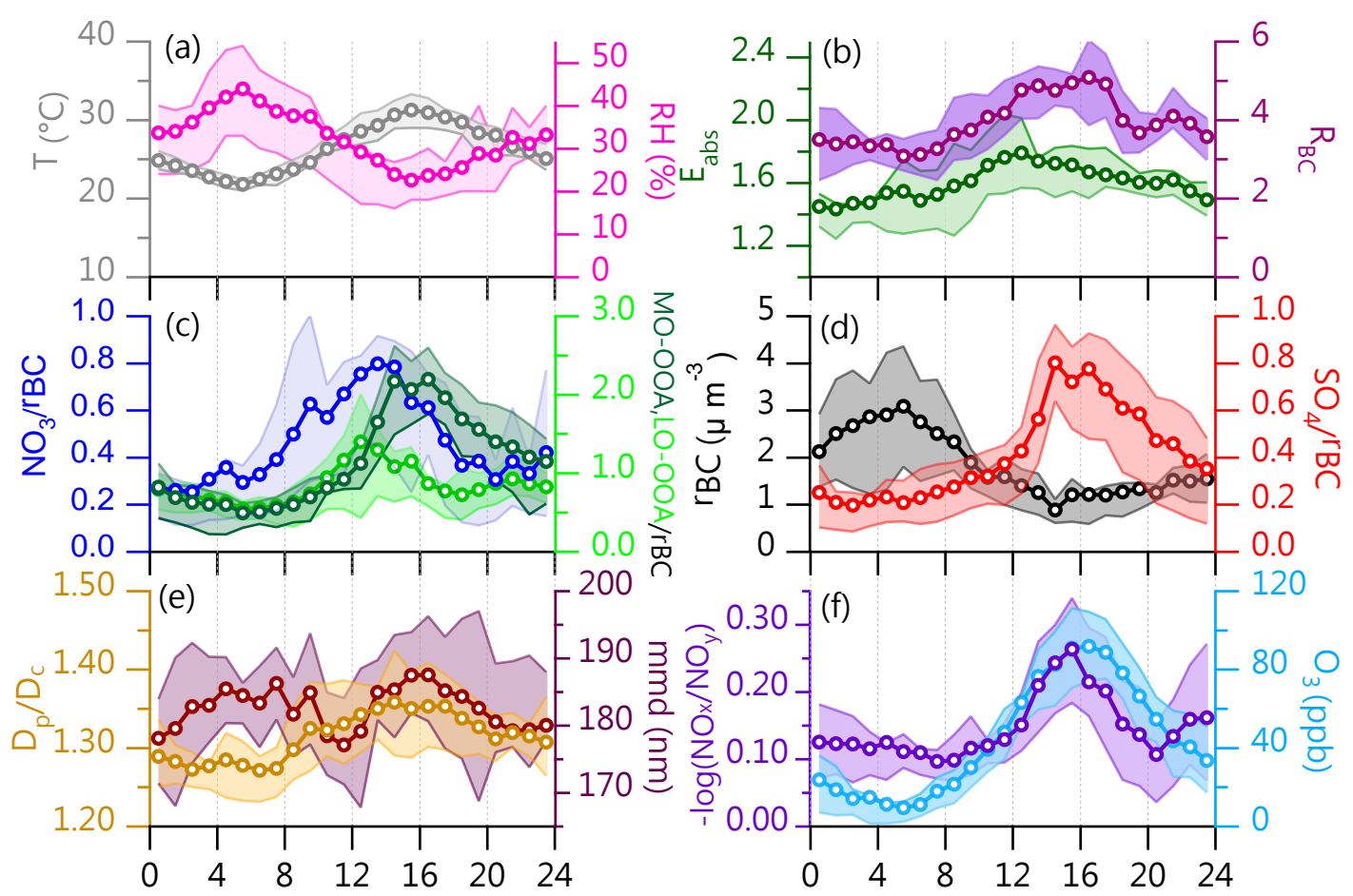

Fig. 4. Diurnal variations of (a) temperature ( $T$ ) and relative humidity $(\mathrm{RH})$, (b) $E_{\mathrm{abs}}$ and $\mathrm{R}_{\mathrm{BC}}$, (c) mass ratios of $\mathrm{NO}_{3}, \mathrm{MO}-\mathrm{OOA}$, and LO-OOA to $\mathrm{rBC}$, (d) $\mathrm{rBC}$ and mass ratio of $\mathrm{SO}_{4}$ to $\mathrm{rBC}$, (e) $D_{\mathrm{p}} / D_{\mathrm{c}}$ and mass median dimeter of $\mathrm{rBC}$, and (f) $-\log \left(\mathrm{NO}_{\mathrm{x}} / \mathrm{NO}_{\mathrm{y}}\right)$ and $\mathrm{O}_{3}$. The circles are mean values, and the shaded areas represent $25^{\text {th }}$ and $75^{\text {th }}$ percentiles. 